\title{
STAN BEZPIECZEŃSTWA W AMERYCE LACIŃSKIEJ W 2016 ROKU
}

Celem niniejszego artykułu jest analiza stanu bezpieczeństwa w Ameryce Łacińskiej w roku $2016^{1}$. Podejmując się owego zadania, konieczne jest wzięcie pod uwagę specyfiki zagrożeń z jakimi borykać się musi ów region, a także samego charakteru bezpieczeństwa tego obszaru. Ameryka Łacińska jest najmniej zmilitaryzowanym regionem świata, przez decydentów politycznych często określanym mianem najbardziej pokojowego. Niewiele jest w nim punktów zapalnych, a konflikty zbrojne między państwami zdarzały się sporadycznie, będąc domeną okresu kształtowania i umacniania niepodległości w wieku XIX. Na mocy podpisanego w 1967 r. Traktatu z Tlatelolco Ameryka Łacińska jest również strefą wolną od broni jądrowej (hiszp. Tratado de Tlatelolco, 1967). Ze względu na niską intensywność zagrożeń, przez dekady region ten pozostawał na uboczu stosunków międzynarodowych, będąc postrzeganym w kategoriach wyłącznej strefy wpływów Stanów Zjednoczonych. Zmiana w tym zakresie nastapiła dopiero na przełomie lat 80. i 90., w związku z zakończeniem zimnej wojny, jak również postępującymi przemianami demokratycznymi w państwach latynoamerykańskich. Procesy te przyczyniły się do redefinicji postrzegania bezpieczeństwa w Ameryce Łacińskiej i dostrzeżenia szerokiej gamy nowych zagrożeń, z których większość nie istniała bądź nie była brana pod uwagę w warunkach dwublokowego podziału świata. Państwa latynoamerykańskie po raz pierwszy zyskały możliwość samodzielnego definiowania najważniejszych dla nich zagrożeń, również tych wychodzących poza tradycyjną płaszczyznę polityczno-militarną (Gawrycki, 2005: 36, 37).

Jak słusznie podkreśla Andrew Hurrell, współczesne zagrożenia dla bezpieczeństwa w Ameryce Łacińskiej nie wynikają z siły państw, potencjału militarnego czy ambicji geopolitycznych, ale wręcz przeciwnie - ze słabości struktur, braku legitymizacji politycznej, łatwości z jaką niestabilność i przemoc rozlewają się z jednego państwa na drugie, tworząc problem międzynarodowy (Hurrell, 1998: 541). Bardzo widoczne jest to na przykładach trapiących ów obszar zagrożeń: przestępczości zorganizowanej, terroryzmu, powszechnego wzrostu przemocy. Oczywiście, Ameryka Łacińska nie jest całkowicie wolna od możliwości wystapienia klasycznych wojen międzypaństwowych, szczególnie biorąc pod uwagę utrzymujące się w regionie spory terytorialne. Nie ulega jednak wątpliwości, iż większość problemów dotykających Amerykę Łacińską ma charakter niemilitarny, wewnętrzny bądź transgraniczny. Podmiotami,

${ }^{1}$ Mianem Ameryki Łacińskiej określa się położony na zachodniej półkuli obszar, rozciągający się od rzeki Rio Grande na północy, do krańców patagońskiej Ziemi Ognistej na południu. W jej skład wchodzą państwa i terytoria zależne, których cechą wyróżniająca jest dominacja języków romańskich, a więc języka hiszpańskiego, języka portugalskiego i języka francuskiego. 
w kontekście których należy owe zagrożenia rozpatrywać, nie są jedynie państwa, ale też jednostki i grupy ludzkie funkcjonujące w ramach struktur państwowych.

Na wstępie należy zwrócić uwagę, iż Ameryka Łacińska jest regionem, w którym wskaźniki przestępczości i przemocy są najwyższe na świecie. Zgodnie z danymi Biura Narodów Zjednoczonych do Spraw Narkotyków i Przestępczości (ang. United Nations Office on Drugs and Crime, UNODC), dochodzi w nim do 30\% światowych zabójstw, z których aż 2/3 dokonywanych jest przy użyciu broni palnej (UNODC, 2014). Na liście 50 najbardziej niebezpiecznych miast świata, aż 41 znajduje się w Ameryce Łacińskiej (Seguridad, Justicia y Paz, 2016). Przyczyny przemocy w Ameryce Łacińskiej są wyjątkowo złożone, a samo zjawisko zakorzenione jest w historii, kulturze i kształtowanych przez długie dekady stosunkach społecznych i politycznych. Społeczna akceptacja dla użycia siły, zarówno w sferze fizycznej, jak i psychicznej, widoczna była w regionie od zarania dziejów, czego skutki widoczne są również obecnie. Mówiąc o bezpieczeństwie w Ameryce Łacińskiej należy więc mieć świadomość, iż jest to region w którym przemoc stanowi element codzienności.

Forma i ramy czasowe artykułu nie pozwalają na przekrojową analizę zagadnień związanych $\mathrm{z}$ naturą przemocy $\mathrm{w}$ regionie, wymuszając skupienie się na wybranych problemach, które odcisnęły swoje piętno na stanie bezpieczeństwa Ameryki Łacińskiej w okresie od 1 stycznia do 31 grudnia 2016 r. W związku z tym, w tekście pominięta zostanie problematyka przemocy domowej, jak również szeroko pojętej przestępczości pospolitej, w którą zaangażowane są wykluczone społecznie jednostki. Pominięcie owych kwestii nie oznacza jednak abstrahowania od ich wpływu na stan bezpieczeństwa w Ameryce Łacińskiej. Brak bezpieczeństwa publicznego jest jednym ze strukturalnych problemów regionu, stanowiąc podatny grunt pod rozwój zorganizowanych form przestępczości.

W niniejszym artykule przedstawione zostaną wydarzenia związane z istniejącymi sporami terytorialnymi, terroryzmem i przestępczością zorganizowaną. Należy zwrócić uwagę, iż kwestie te bardzo często przenikają się między sobą, co utrudnia analizowanie ich w sposób niezależny od siebie, zachęcając do podejścia holistycznego.

\section{SPORY TERYTORIALNE}

Cechą charakterystyczną sporów terytorialnych w Ameryce Łacińskiej jest ich długotrwały charakter. W większości sięgają one swoimi korzeniami czasów dekolonizacji i wytyczania granic między państwami (Wojna, 2008: 496). Mimo iż spory terytorialne nie stanowią kluczowych problemów współczesnej Ameryki Łacińskiej, a spora część z nich została już rozwiązana, w 2016 r. zauważyć można było kilka punktów zapalnych, mogących stanowić zarzewie potencjalnego konfliktu zbrojnego.

$\mathrm{Na}$ uwagę w omawianym kontekście bez wątpienia zasługują dążenia Boliwii do uzyskania dostępu do morza, utraconego na korzyść Chile w wyniku „wojny o saletrę” (1879-1884). Spór ten nie przybrał do tej pory agresywnego charakteru, mimo iż od ponad czterdziestu lat państwa nie utrzymują ze sobą stosunków dyplomatycznych. Intensywność sporu między państwami wzrosła w okresie prezydentury Evo Moralesa w Boliwii, którego rząd konsekwentnie dąży do umiędzynarodowienia problemu, 
czego dowodem było skuteczne wniesienie sprawy do Międzynarodowego Trybunału Sprawiedliwości (MTS). Jednocześnie zaś, sam E. Morales wykazuje wyjątkową nieufność w stosunku do poczynań chilijskich. W maju 2016 r. oskarżył władze Chile o utworzenie bazy wojskowej jedynie $15 \mathrm{~km}$ od granicy z Boliwią, i co za tym idzie: o kreowanie celowego zagrożenia dla bezpieczeństwa Boliwii. „Nie rozumiem powodów decyzji Chile o stworzeniu bazy militarnej. Jest ona nielegalna w świetle konwencji międzynarodowych. Tego typu instalacje powstawać mogą co najmniej $50 \mathrm{~km}$ od strefy granicznej" - mówił E. Morales w czasie oficjalnego orędzia (Ramos, Esposito, 2016). Boliwijski prezydent nie sprecyzował jednak, na jaki akt prawa międzynarodowego powoływał się w przemówieniu. Chilijskie Ministerstwo Spraw Zagranicznych zaprzeczyło oskarżeniom. Zwiększona obecność wojsk związana była z intensyfikacją patroli, chroniących ludność cywilną przed atakami ze strony przybywających z terenów Boliwii przemytników narkotyków (Ramos, Esposito, 2016). Warto zwrócić uwagę, iż osią sporu dwóch państw jest również użytkowanie zasobów rzeki Silala, mającej swoje źródła w Boliwii, ale traktowanej przez Chile jako rzeka międzynarodowa. Władze boliwijskie, zdaniem których wody Silali płyną przez terytorium Chile dzięki kanałom zbudowanym sztucznie na początku XX w., od lat oskarżają władze Chile o nielegalne ich użytkowanie. Ponowne podniesienie tej kwestii przez rząd E. Moralesa w marcu 2016 r. spotkało się z ostrą reakcją władz Chile. Prezydent Michelle Bachelet ogłosiła w czerwcu, iż kwestia uznania Silali za rzekę międzynarodową skierowana została do MTS (Montes, 2016).

Rok 2016 był istotny również z punktu widzenia wenezuelsko-gujańskiego sporu o Esequibę, region stanowiący ponad połowę terytorium Gujany. Wenezuelskie roszczenia w stosunku do tego terytorium sięgają czasów kolonialnych, jednak w ostatnich latach, w wyniku odkrycia na tych terenach złóż ropy naftowej, zintensyfikowały się. W grudniu 2016 r., pośrednicząca w negocjacjach między państwami Organizacja Narodów Zjednoczonych wyznaczyła stronom okres 12 miesięcy, w którym muszą dojść do porozumienia w sprawie Esequiby. W przeciwnym razie, zgodnie z sugestią wysuniętą przez ówczesnego Sekretarza generalnego ONZ Ban Ki-moona, spór powinien być skierowany do Międzynarodowego Trybunału Sprawiedliwości (La ONU llevará a la CIJ, 2016).

Do istotnych napięć doszło w 2016 r. również w stosunkach Belize z Gwatemalą. 20 kwietnia 2016 r. na pograniczu dwóch państw doszło do incydentu, w wyniku którego zginął nastoletni Gwatemalczyk, a jego ojciec i brat zostali ranni. Zdaniem władz gwatemalskich, winnymi śmierci chłopca byli żołnierze Belize, którzy dokonali w stosunku do obywateli Gwatemali „tchórzliwego i nieproporcjonalnego” ataku. Gwatemalskiej wersji wydarzeń zaprzeczył jednak premier Belize Dean Barrow. Jego zdaniem wojska belizyjskie działały w obronie własnej, w odpowiedzi na skierowany przeciwko nim atak z broni palnej. Dodatkowo podkreślił on, iż żołnierze ci poruszali się w towarzystwie lokalnej grupy pracowników cywilnych, którzy byli świadkami całego zdarzenia. Incydent potraktowany został przez władze gwatemalskie jako prowokacja, co poskutkowało decyzją o rozlokowaniu na granicy z Belize dodatkowych trzech tys. żołnierzy (Guatemalan troops mass, 2016, Guatemala despliega 3.000 soldados, 2016). Należy podkreślić, iż kwietniowy incydent doprowadził do wzrostu poczucia zagrożenia wśród Gwatemalczyków zamieszkujących tereny przygraniczne. 
Część z nich, w obawie przed agresją ze strony Belize, zdecydowała się opuścić swoje domy (Darío Melgar Choc, 2016).

Mówiąc o sporach terytorialnych warto poświęcić miejsce kwestii argentyńskobrytyjskiego sporu o archipelag Falklandów-Malwinów. Argentyńskie roszczenia w stosunku do wysp sięgają XIX w., kiedy w wyniku zbrojnej agresji zaanektowane one zostały przez Wielką Brytanię. W ostatnich latach spór o Falklandy stał się szczególnie głośny za sprawą nacjonalistycznej kampanii rozpętanej przez prezydent Cristinę Fernández de Kirchner, domagającej się od władz Wielkiej Brytanii negocjacji w sprawie suwerenności wysp. W roku 2016 r., w związku ze zmianą władzy w Argentynie i objęciem funkcji prezydenta przez Mauricia Macriego, retoryka dotycząca kwestii falklandzkiej uległa złagodzeniu. Władze Argentyny nie zrezygnowały jednak $\mathrm{z}$ roszczeń w stosunku do wysp, co znalazło swoje potwierdzenie w przemówieniu prezydenta Macriego na forum Organizacji Narodów Zjednoczonych oraz w nieformalnej rozmowie z brytyjską premier Theresą May (Obarrio, 2016). Z punktu widzenia Argentyny, brytyjska suwerenność nad Falklandami nierozerwalnie związana jest z militaryzacją południowego Atlantyku, co stanowi poważne zagrożenie dla regionalnego bezpieczeństwa.

\section{TERRORYZM}

Terroryzm w Ameryce Łacińskiej w pierwszej kolejności związany jest z działającymi na poziomie lokalnym grupami partyzanckimi wyznającymi lewicową ideologię (Wojna, 2008: 487). Według amerykańskiego Departamentu Stanu, w Ameryce Łacińskiej działają obecnie trzy ugrupowania terrorystyczne: kolumbijskie Rewolucyjne Siły Zbrojne Kolumbii (hiszp. Fuerzas Armadas Revolucionarias de Colombia - Ejército del Pueblo, FARC) i Armia Wyzwolenia Narodowego (hiszp. Ejército de Liberación Nacional, ELN) oraz peruwiański Świetlisty Szlak (hiszp. Sendero Luminoso, $\mathrm{SL})$.

Powstały w 1964 r. FARC jest największą grupą partyzancką zaangażowaną w kolumbijską wojnę domową, jednak w ostatnich latach potencjał jej działania znacząco zmalał. W wyniku prowadzonych od 2012 r. rozmów między kolumbijskim rządem a partyzantami, we wrześniu $2016 \mathrm{r}$. podpisany został historyczny układ pokojowy. Na jego mocy, dojść miało do kontrolowanej przez Narody Zjednoczone demilitaryzacji FARC, który w zamian za amnestię i pomoc finansową dla większości byłych członków bojówki, funkcjonować miał od tej pory jako legalna siła polityczna w państwie (Fajardo, 2016). Porozumienie nie znalazło jednak poparcia większości Kolumbijczyków, którzy stosunkiem głosów 50,2\% do 49,8\%, przy niecałych 60 tys. przewagi głosów na „nie”, odrzucili je w przeprowadzonym 2 października 2016 r. referendum (Brodzinsky, 2016). Niesatysfakcjonujący dla negocjujących stron rezultat traktować można jako efekt społecznego postrzegania FARC jako synonimu brutalności i przemocy, jak również poczucia niesprawiedliwości w stosunku do tysięcy ofiar guerrilli. Trzeba jednak podkreślić, iż wynik październikowego referendum stanowił odbicie prostych mechanizmów psychologicznych, w tym prowadzonej przez przeciwników porozumienia kampanii strachu. W okręgach wiejskich, najbardziej dotkniętych dzia- 
łalnością terrorystyczną FARC, liczba zwolenników porozumienia, a tym samym zakończenia fali przemocy, była przeważająca. O odrzuceniu referendum zdecydowali jednak głównie mieszkańcy miast, którzy nie doświadczyli konfliktu z FARC bezpośrednio (Asi fueron las votaciones, 2016). Warto również zwrócić uwagę na rekordowo niską frekwencję - jedynie 37,4\% uprawnionych do głosowania. W obliczu negatywnego wyniku referendum, 12 listopada 2016 r. doszło między stronami do wypracowania nowej wersji porozumienia. Najważniejszą zmianą w stosunku do pierwszej jego wersji było zaostrzenie kar dla partyzantów odpowiedzialnych za najcięższe zbrodnie - podstawowe założenia pozostały jednak niezmienione. Drugi układ z FARC nie wiązał się ze zorganizowaniem drugiego referendum, a jego wejście w życie uzależnione było od akceptacji przez kolumbijski Kongres, co nastąpiło w dniu 30 listopada $2016 \mathrm{r}$. (Congreso refrendó el nuevo acuerdo de Paz, 2016).

O przełomie mówić można również w stosunkach władz kolumbijskich z ELN. Ugrupowanie to przez dwa lata prowadziło wstępne rozmowy z przedstawicielami rządu prezydenta Santosa, a oficjalna gotowość do rozpoczęcia negocjacji pokojowych zadeklarowana została przez dwie strony sporu w marcu 2016 r. (Cosoy, 2016).

Nie ulega wątpliwości, iż wypracowanie i przyjęcie porozumienia z FARC, jak również decyzja na temat rozpoczęcia rozmów z ELN, stanowią przełom z punktu widzenia bezpieczeństwa regionalnego. Stosunek obywateli do przeprowadzonego w październiku referendum w sprawie FARC pokazuje jednak, że mieszkańcy Kolumbii, nawet ci w najmniejszym stopniu doświadczający przemocy, w dalszym ciągu podatni są na argumenty strachu. Co więcej, zakończenie konfliktu z bojówkami nie oznacza całkowitego rozwiązania problemu przemocy w Kolumbii. Zgodnie z danymi organizacji pozarządowej Indepaz (hiszp. Instituto de Estudios para el Desarrollo y la Paz), w roku 2016 w Kolumbii doszło do rekordowo wysokiej liczby zabójstw aktywistów społecznych i obrońców praw człowieka - życie straciło aż 117 osób (Indepaz, 2016). Odpowiedzialnymi za owe morderstwa są w zdecydowanej większości paramilitarne grupy parające się handlem narkotykami (narcoparamilitares), przez lata rywalizujące z FARC o zyski i wpływy. Mimo iż liderzy negocjujących z rządem guerrillas zdecydowanie odcięli się od ataków, do których w dalszym ciągu dochodzi w państwie, rząd Kolumbii obawia się, że utrzymująca się fala przemocy zagrozić może procesowi pokojowemu, którego implementacja obecnie jest podejmowana (Almonacid, 2017).

Świetlisty Szlak, działająca w Peru partyzantka odwołująca się do ideologii maoistowskiej, w dalszym ciągu pozostaje aktywna, szczególnie w dolinie rzek Apurímac, Ene i Mantaro (hiszp. Valle de los ríos Apurímac, Ene y Mantaro, VRAEM). Kontrolę nad tym trudno dostępnym obszarem od lat pragną odzyskać siły rządowe. W kwietniu 2016 r., w przededniu wyborów prezydenckich, doszło do ataku terrorystycznego w miejscowości Hatunccasa, w wyniku którego śmierć poniosło ośmiu wojskowych i dwóch cywili, a pięć kolejnych osób zostało rannych. Wchodzili oni w skład konwoju, który oddelegowany był do ochrony urn wyborczych w andyjskiej miejscowości Matichaca (Perú: 10 muertos, 2016). Świetlisty Szlak odpowiedzialny był również za wiele innych, pomniejszych ataków na wojskowych, do których doszło w okresie przedwyborczym. W maju 2016 r. wojskowym udało się namierzyć wysokiego dowódcę partyzantki na obszarze andyjskim, Alejandra (lub Abla) Auqui 
Lópeza. Zginął on w trakcie wymiany ognia. Wydarzenie to określone zostało przez peruwiańskie Ministerstwo Obrony jako poważny cios zadany Świetlistemu Szlakowi i ważny krok w pacyfikacji bojówkarzy na obszarze VRAEM (Matan a un alto mando, 2016). Tocząca się od wielu lat wojna pomiędzy maoistowską partyzantką a wojskiem ma bezpośredni wpływ na życie mieszkańców prawie 50 dystryktów, w których od dekad panuje stan wyjątkowy. Jednostki te żyją w permanentnym poczuciu zagrożenia, nie mogąc przy tym w pełni cieszyć się prawem do swobodnego poruszania się i zgromadzeń (Fowks, 2016).

Osobnym, wartym rozważenia problemem jest kwestia występowania w Ameryce Łacińskiej terroryzmu podyktowanego fundamentalizmem islamskim. W latach 90. $\mathrm{w}$ regionie dwukrotnie doszło do tego typu aktów terroru² ${ }^{2}$ Obecnie, w związku z rosnącą ilością ataków przeprowadzanych w Afryce, Azji i Europie przez zwolenników tzw. Państwa Islamskiego (ISIS), zagrożenie ze strony fundamentalizmu islamskiego ponownie stało się aktualnym tematem w Ameryce Łacińskiej. Szacuje się, że wśród 27 tys. cudzoziemców, którzy dołączyli do ISIS od 2011 r., ponad 70 pochodziło z Ameryki Łacińskiej. Zdaniem sekretarza generalnego Organizacji Państw Amerykańskich, Luisa Almagro, liczba ta jest wystarczająca do przeprowadzenia potencjalnego ataku terrorystycznego w Ameryce Łacińskiej (Oppenheimer, 2016). 9 marca 2016 r. w urugwajskiej miejscowości Paysandú, mężczyzna określający się jako zwolennik Państwa Islamskiego zabił żydowskiego przedsiębiorcę Davida Fremda, zadając mu kilka ciosów nożem. Wydarzenie to potraktowane zostało jako atak o charakterze antysemickim, niemniej wyraźna sympatia urugwajskiego muzułmanina wobec treści głoszonych przez ISIS może niepokoić. Nie ulega wątpliwości, iż potencjalna obecność fundamentalizmu islamskiego w Ameryce Łacińskiej wymaga dalszego monitorowania (Píriz, Correa, 2016).

\section{PRZESTĘPCZOŚĆ ZORGANIZOWANA}

Przestępczość zorganizowana stanowi jedno z największych wyzwań stojących obecnie przed Ameryką Łacińską, będąc jednocześnie podstawowym zagrożeniem dla bezpieczeństwa na tym obszarze. Pod pojęciem zorganizowanych grup przestępczych rozumieć należy takie struktury, których członkowie podejmują nielegalne działania - handel narkotykami, handel ludźmi, handel bronią, masowe kradzieże, porwania - celem osiagnnięcia zysku. Problem ten w mniejszym bądź większym stopniu dotyczy wszystkich państw Ameryki Łacińskiej, a pogłębiająca się dywersyfikacja działań podejmowanych przez zorganizowanych grupy przestępcze utrudnia ukrócenie tego procederu przez służby państwowe. Zdecydowana większość morderstw, do których dochodzi w Ameryce Łacińskiej, powiązana jest z przestępczością zorganizowaną (Morán Blanco, 2010: 67).

${ }^{2}$ W 1992 r. doszło do ataku bombowego na ambasadę Izraela w Buenos Aires, w wyniku którego śmierć poniosło 29 osób, a ponad 240 zostało rannych. Dwa lata później, również w Buenos Aires, eksplodowało żydowskie centrum kulturalne AMIA (hiszp. Asociación Mutual Israelita Argentina), zabijając 85 osób i raniąc ponad 300. Odpowiedzialność za obydwa zamachy przypisuje się grupom powiązanym z Hezbollahem. Nie wyklucza się możliwości, iż działały one z inspiracji i dzięki finansowemu wsparciu rządu Iranu. 
Mówiąc o zorganizowanych grupach przestępczych w Ameryce Łacińskiej, za najbardziej kompleksową, poważną i rozległą formę ich działania uznać należy handel narkotykami. Jest to również największy problem transnarodowy - państwa latynoamerykańskie od lat dominują na liście największych producentów lub państw tranzytowych narkotyków. Kartele narkotykowe to grupy bezwzględne, uciekające się do przemocy i korupcji, nierzadko posiadające szerokie wpływy polityczne. Handel narkotykami, stanowiąc łatwe i przy dobrej organizacji stosunkowo bezpieczne źródło dochodów, bardzo często powiązany jest z innymi formami przestępczości zorganizowanej, jak również z terroryzmem (Spyra, 2006: 61). Potwierdzić to moga przypadki Kolumbii i Peru, państw w których uprawia się najwięcej nielegalnych krzewów koki na świecie. Kolumbijski FARC przez lata traktowany był jako najważniejszy gracz na światowym rynku kokainy, a wielu członków demobilizowanej bojówki w dalszym ciągu czerpie zyski z tego procederu. Narkobiznes stanowi również jedną z najważniejszych płaszczyzn działań Świetlistego Szlaku, wykorzystującego fakt, iż to właśnie w Andach produkuje się na masową niemal skalę pastę kokainową (Insight Crime Foundation, 2016: 45). Nie ulega jednak wątpliwości, iż państwem, które w ostatnich latach najbardziej dotknięte zostało skutkami działalności karteli narkotykowych jest Meksyk. W 2016 r. minęła dziesiąta rocznica decyzji władz federalnych o zaangażowaniu wojsk do walki z kartelami. 2006 r. określić więc można jako początek wojny domowej pomiędzy siłami rządowymi a grupami narcos. Z perspektywy dekady coraz częściej określa się ów konflikt jako wielką porażkę władz państwowych (Fregoso, 2016; Cacelín, 2016; Paullier, 2016). Tylko w 2016 r. zarejestrowanych zostało 22935 intencjonalnych zabójstw, z których ponad połowa związana była z przestępczością zorganizowaną. Był to najwyższy wynik od sześciu lat (Secretaría de Gobernación, 2017: 2). Ogromna skala zjawiska, sprowadzająca się do kilkudziesięciu zabójstw dziennie, uniemożliwia odniesienie się do wszystkich przypadków. Wyjątkowo głośnym echem odbiło się jednak październikowe morderstwo sędziego federalnego Vicenta Bermúdeza Zacaríasa, który prowadził sprawy przeciwko wielu baronom narkotykowym. Zdecydował on między innymi o odrzuceniu apelacji od decyzji o ekstradycji do Stanów Zjednoczonych, złożonej przez byłego szefa kartelu z Sinaloa, Joaquína Guzmána, znanego jako El Chapo (Reina, 2016). Sam J. Guzmán, który wcześniej kilkukrotnie uciekał z więzienia, ujęty został przez meksykańską piechotę morską w dniu 19 stycznia 2016 r. Warto zwrócić uwagę, iż 27 grudnia 2016 r. aresztowany został również Rodolfo López Ibarra, znany jako el Nito Amavizca. Był on jednym z przywódców kartelu Beltrán-Leyva, oryginalnie działającego jako odłam kartelu z Sinaloa (Sánchez, 2016). Doświadczenie pokazuje jednak, iż sukcesy sił rządowych w rozbijaniu struktur władzy karteli nie prowadzą do rozwiązania problemu narkotykowego w Meksyku. Na miejsce starych organizacji pojawiają się bowiem nowe, a upadli liderzy zastępowani są nowymi przywódcami. W lutym $2016 \mathrm{r}$. w stanie Michoacan utworzony został nowy kartel o nazwie Nowa Rodzina (hiszp. La Nueva Familia Michoacana), którego członkowie wypowiedzieli wojnę najpotężniejszemu obecnie meksykańskiemu kartelowi, Nowej Generacji Jalisco (Castellanos, 2016). Dobrym przykładem może być również przypadek Rafaela Caro Quintero, założyciela kartelu z Guadalajary, w latach 80. jednego z najbardziej znanych baronów narkotykowych, obecnie ukrywającego się przed wymiarem sprawiedliwości. W lipcu 
2016 r. przerwał on milczenie. Zdaniem władz meksykańskich, celem Caro Quintero jest odzyskanie władzy i przejęcie wpływów osłabionego aresztowaniem El Chapo Guzmana kartelu z Sinaloa (Martínez Ahrens, 2016).

Należy zwrócić uwagę, iż narkobiznes stanowi standardową płaszczyznę działania dla organizacji przestępczych $\mathrm{w}$ całym regionie, co związane jest $\mathrm{z}$ rosnącym popytem na używki. Problem wzmożonej konsumpcji narkotyków, głównie kokainy, bardzo widoczny jest w Ameryce Południowej, szczególnie w Argentynie, Brazylii, Urugwaju, Chile, Paragwaju. To właśnie w tych państwach notuje się wyraźny wzrost aktywności grup przestępczych zaangażowanych w narkobiznes. Nieformalnym centrum paragwajskich wojen narcos stało się miasto Pedro Juan Caballero, w którym, w przeciagu kilku zaledwie dni, w wyniku porachunków zamordowany został baron narkotykowy Jorge Rafaat Toumani, alias „Sadam”, jak również szereg innych powiązanych z narkobiznesem jednostek (Guerra narco en Paraguay, 2016; Sigue la guerra narco, 2016). W Argentyńskich miastach Rosario i Santa Fe w 2016 r. rekordowo wzrosła skala przemocy i korupcji związanej z lokalnym handlem narkotykami. Spadek poziomu bezpieczeństwa na tym tle zanotowany został również w Buenos Aires, gdzie lokalny rynek zdominowany został przez peruwiańskich i boliwijskich przestępców (Insight Crime Foundation, 2016: 46). Handel narkotykami stanowi również istotne źródło dochodu dwóch największych grup przestępczych w Brazylii - działającego w Rio de Janeiro Czerwonego Komando (port. Comando Vermehlo, CV) oraz związanego z Săo Paulo Pierwszego Komando Stolicy (port. Primeiro Comando da Capital, PCC). Gangi te przez lata dzieliły się strefami wpływów, a ich członkowie utrzymywali ze sobą pokojowe stosunki. Sytuacja zmieniła się jednak pod koniec 2016 r. W październiku, w wyniku zamieszek wywołanych przez PCC w więzieniu w Rio de Janeiro, śmierć poniosło 18 osób, w tym członkowie PV. Wydarzenie to stanowiło jedną z przyczyn zerwania sojuszu dwóch gangów, doprowadzając do eskalacji przemocy i znaczącego spadku bezpieczeństwa w Rio de Janeiro, będącego areną krwawych konfrontacji między grupami przestępczymi (Insight Crime Foundation, 2016: 45).

Wzrost aktywności grup przestępczych parających się handlem narkotykami zanotowany został również w Ameryce Środkowej. Obszar ten, kluczowy z punktu widzenia przerzutu narkotyków z Ameryki Południowej do Północnej, tradycyjnie znajdował się pod wpływem karteli meksykańskich. Funkcjonujące na tych terenach grupy przestępcze działały na lokalną skalę, stanowiąc niewielkie ogniwa nielegalnego procesu. W ostatnich latach jednak, coraz częściej mówi się o zmianie charakteru narkobiznesu w Ameryce Środkowej - stopniowym uniezależnianiu się lokalnych karteli i tworzeniu przez ich liderów transnarodowych grup przestępczych. Dwa największe gangi panamskie, Calor Calor i Bagdad, podjęły się konsolidacji pomniejszych organizacji przestępczych w celu przejęcia kontroli nad krajowymi szlakami przerzutu narkotyków. Murillo Barberena, stojący na czele gangu Kill the Nasty, szeroko współpracował z kolumbijskimi handlarzami narkotyków, z powodzeniem angażując się w transnarodową działalność przestępczą (Yagoub, 2016). W październiku 2016 r., w wyniku wspólnej operacji oddziałów z Kolumbii i Panamy, ujęty został Héctor Moisés Murillo Barberena, jeden z najbardziej poszukiwanych obywateli panamskich. Zgodnie z badaniami przeprowadzonymi w Panamie, na obszarach, na których gangi są najsilniejsze, wskaźnik zabójstw jest najwyższy. Wpisuje się to w ogólny 
trend panujący w Ameryce Łacińskiej (Insight Crime Foundation, 2016: 31). W listopadzie 2016 r. władze Kostaryki ogłosiły rozbicie ,pierwszej w historii struktury kryminalnej, zarządzającej wszystkimi aspektami handlu narkotykami z Kostaryki” (ibid.: 30). Grupa, współpracująca z meksykańskim kartelem z Sinaloa, importowała kokainę z Ekwadoru i Kolumbii, przesyłając ją później na północ Meksyku (Clavel, 2016). Sama Kostaryka, na tle Ameryki Środkowej postrzegana jako bezpieczne i dobrze prosperujące państwo, boryka się z coraz większym problemem przestępczości zorganizowanej i handlu narkotykami, szczególnie w karaibskiej prowincji Limón. W październiku 2016 r. doszło tam do głośnej strzelaniny, w wyniku której zginęło pięć osób, w tym 11-letnie dziecko (Jiménez, 2016). W związku z eskalacją przemocy, władze federalne zdecydowały o wysłaniu do Limón 400 dodatkowych policjantów. W poprawę stanu bezpieczeństwa w Kostaryce zaangażowały się również Stany Zjednoczone, które przeznaczyły na ten cel 30 mln dolarów (Insight Crime Foundation, 2016: 31). Mówiąc o walce z przestępczością zorganizowaną, nie można jednak nie wspomnieć o sukcesie kostarykańskich służb, które w listopadzie 2016 r., we współpracy z władzami Hondurasu i Stanów Zjednoczonych, ujęły przywódcę honduraskiego kartelu Atlantyk, Wiltera Neptalí Blanco Ruíza. Sam Honduras w dalszym ciągu pozostaje jednym z najbardziej niebezpiecznych państw, z najwyższym na świecie wskaźnikiem zabójstw - 84,6 w przeliczeniu na 100 tys. mieszkańców. W pierwszej dziesiątce państw znajduje się też Belize - szóste miejsce, 34,3 w przeliczeniu na 100 tys. mieszkańców, jak również Gwatemala - dziewiąte miejsce, 31,2 w przeliczeniu na 100 tys. mieszkańców (Murder Rates by Country, 2016).

Przestępczość zorganizowana od lat stanowi ogromny problem w Salwadorze. Po zakończeniu wojny domowej w 1992 r., przebywający w amerykańskich więzieniach członkowie gangów i grup przestępczych deportowani zostali do ojczyzny, ,importując" przemoc wraz ze sobą. Dwa największe działające obecnie w Salwadorze gangi, Mara Salvatrucha (MS-13) oraz Barrio 18 (dzielący się na dwie frakcje: Revolucionarios i Sureńos) tradycyjnie znajdowały się między sobą w stanie wojny. W marcu 2016 r. jednak, ich liderzy ogłosili rozejm, mający na celu ukrócenie fali przemocy w państwie. Mimo iż większość obserwatorów nie wierzy w trwałość zawiązanego porozumienia, traktując sojusz jako rozwiązanie jedynie czasowo ograniczające eskalację przemocy, sami liderzy gangów w sposób coraz bardziej otwarty wypowiadają się na temat potencjalnych negocjacji z rządem Salwadoru. Członkowie Barrio 18 i MS-13 sugeruja, iż mediatorem w sprawie potencjalnego porozumienia powinni być przedstawiciele społeczności międzynarodowej (Partlow, Maslin, 2016). Tymczasem mimo ograniczenia walk wewnątrz gangów, w dalszym ciagu dochodzi w Salwadorze do aktów przemocy wobec obywateli. W kwietniu 2016 r. zamordowany został burmistrz miejscowości San Dionisio, Julio Torres, w marcu natomiast, ośmiu pracowników firmy telekomunikacyjnej i trzech zbieraczy trzciny. Efektem owych zajść było wprowadzenie przez rząd dodatkowych środków w walce przeciwko gangom, w tym ograniczenia możliwości kontaktu z ich osadzonymi w więzieniach członkami (Sube a 11 cifra de asesinados, 2016; Encuentran cadáver del alcalde, 2016).

Problemem uniemożliwiającym skuteczną walkę z przestępczością zorganizowaną jest wysoki stopień korupcji, zarówno wśród polityków, jak i walczących z kartelami służb mundurowych i wojska. Nadużycia, a wręcz bezpośrednie powiązania człon- 
ków elit rządzących z grupami przestępczymi, najczęściej kartelami narkotykowymi, stanowią w Ameryce Łacińskiej rzecz powszechną, obniżając zaufanie obywateli do władzy i uniemożliwiająca poprawę stanu bezpieczeństwa. Bardzo często dochodzi bowiem do sytuacji, w której same instytucje państwowe przyczyniają się do utrzymywania zagrożeń, z którymi w oficjalnym dyskursie starają się walczyć. Dowody na istnienie tego zjawiska znaleźć można w każdym państwie latynoamerykańskim, jednak najlepszym przykładem ilustrującym jego skalę jest Wenezuela, państwo przez które przechodzi zdecydowana większość produkowanej w Kolumbii kokainy. Informacje o powiązaniach reżimu wenezuelskiego $\mathrm{z}$ narkobiznesem obecne były w debacie publicznej już od końca lat 90. XX w., ale o potwierdzeniu tych doniesień mówić można dopiero w ostatnich latach, w związku z falą aresztowań czołowych polityków, wojskowych i członków elit, oskarżanych o czerpanie zysków z handlu narkotykami. Obecnie nikt nie wątpi już w związki przedstawicieli kręgów władzy z kontrolującym przerzut kokainy Kartelem Stońc (hiszp. Cartél de los Soles). Jedynie w pierwszym kwartale 2016 r. zatrzymanych zostało na tym tle kilkunastu prominentnych wenezuelskich wojskowych (Daugherty, 2016). W czerwcu 2016 r. na terenie Kolumbii aresztowany został wenezuelski pilot wojskowy, pracujący niegdyś dla pierwszej damy (Delgado, 2016). Skala powiązań pracowników rządowych z przestępczością zorganizowaną jest tak duża, iż komentatorzy nie oponują przed określaniem Wenezueli mianem narkopaństwa (Semprun, 2016; Fleischman, 2016; Usi, 2016).

$* * *$

Rok 2016 w Ameryce Łacińskiej postrzegać należy jako istotny z punktu widzenia bezpieczeństwa regionalnego. Bez wątpienia najważniejszym wydarzeniem do jakiego doszło w tym okresie było porozumienie rządu Kolumbii z najstarszą i największą grupa paramilitarną FARC. Wydarzenie to było szeroko komentowane przez społeczność międzynarodowa, a stojący na czele kolumbijskiego rządu prezydent Juan Manuel Santos uhonorowany został Pokojową Nagrodą Nobla. Wyróżnienie to pozytywnie kontrastuje z postawą wielu przedstawicieli latynoamerykańskich elit, często skorumpowanych i nieefektywnych w walce z obecnymi w regionie zagrożeniami. Rok 2016 potwierdza, iż najpoważniejsze wyzwania dla bezpieczeństwa Ameryki Łacińskiej mają charakter wewnętrzny, nie zaś międzypaństwowy. Istniejące w regionie spory terytorialne cechują się bowiem niską intensywnością, a jedyna eskalacja nastapiła w 2016 r. na granicy Gwatemali i Belize.

Nie ulega również wątpliwości, iż największym problemem Ameryki Łacińskiej jest przestępczość zorganizowana. Zjawisko to obecne jest we wszystkich państwach, przyczyniając się do rekordowych wskaźników skali przemocy notowanych w regionie również w $2016 \mathrm{r}$. Opisane w artykule wydarzenia potwierdzają, iż formy działalności zagrażającej bezpieczeństwu regionalnemu przenikają się, jednak praktycznie każda zorganizowana grupa przestępcza zaangażowana jest $w$ handel narkotykami. Narkobiznes stanowi największe źródło nielegalnego dochodu, co związane jest ze stale rosnącym popytem na używki, widocznym również w samej Ameryce Łacińskiej. Wydarzenia z 2016 r. potwierdzają, iż nielegalny handel narkotykami to ogromne wyzwanie zarówno na obszarach stabilnych, takich jak Kostaryka czy pań- 
stwa Cono Sur, jak i tych przeżywających poważne problemy społeczno-polityczne, jak Wenezuela.

Uznać należy, iż zagrożenia w Ameryce Łacińskiej w 2016 r. jedynie potwierdzają, iż bezpieczeństwo $\mathrm{w}$ regionie tym rozpatrywać należy w pierwszej kolejności w kategoriach jednostek ludzkich, nie zaś samych państw. Jak podkreślone zostało bowiem we wstępie, to nie siła militarna podmiotów państwowych, czy też geopolityczne ambicje rządzących stanowią główne przyczyny poczucia braku bezpieczeństwa wśród zamieszkujących Amerykę Lacińską jednostek.

\section{PROGNOZY}

\section{Prognoza krótkoterminowa (2017 r.)}

Ze względu na specyfikę zagrożeń występujących w Ameryce Łacińskiej, z których większość ma charakter przewlekły, trudno jest spodziewać się znaczących zmian w stanie bezpieczeństwa na tym obszarze w 2017 r. Należy jednak pamiętać, iż rok 2017 to w Stanach Zjednoczonych pierwszy rok rządów administracji Donalda Trumpa. Polityk ten postrzega Latynosów, szczególnie zaś licznie zamieszkujących USA Meksykanów, jako zagrożenie dla bezpieczeństwa ekonomicznego i społecznego Stanów Zjednoczonych. Propozycja budowy muru i znaczące wzmocnienie kontroli na granicy amerykańsko-meksykańskiej wpłyną nie tylko na stosunki polityczno-dyplomatyczne dwóch państw, ale mogą mieć również wpływ na bezpieczeństwo latynoamerykańskich migrantów, próbujących przekroczyć granicę w sposób nielegalny, często tracąc przy tej okazji życie lub zdrowie.

Nie można wykluczać, iż w 2017 r. na obszarach przygranicznych państw toczących ze sobą spory terytorialne dochodzić będzie do kolejnych incydentów, podobnych do tych, który w 2016 r. miał miejsce na pograniczu belizyjsko-gwatemalskim. Nie wolno bagatelizować tego typu wydarzeń. Doświadczenia historyczne, takie jak wojna futbolowa z 1969 r. między Salwadorem i Hondurasem, czy inwazja wojsk Nikaragui na Kostarykę w 2010 r. ${ }^{3}$, ukazują bowiem, iż do eskalacji konfliktu między państwami, których stosunki od lat są napięte, dojść może z błahych przesłanek. Mimo to, zagrożenie wybuchem regularnej wojny w Ameryce Łacińskiej w 2017 r. jest w dalszym ciagu niewielkie.

Rok 2017 bez wattpienia będzie kluczowy dla powodzenia procesu pokojowego w Kolumbii. W życie wchodzić zaczną bowiem zapisy porozumienia rządowego z bojówką FARC. Najważniejszą z punktu widzenia bezpieczeństwa kwestią będzie

${ }^{3}$ Bezpośrednią przyczyną konfliktu określonego przez Ryszarda Kapuścińskiego mianem „wojny futbolowej” był przegrany 15 czerwca 1969 r. przez Honduras mecz piłki nożnej. Wydarzenie to stanowiło punkt kulminacyjny fali wrogości w stosunku do Salwadorczyków, prowadząc do szeregu incydentów przygranicznych, zerwania stosunków dyplomatycznych, aż wreszcie inwazji wojsk Salwadoru na Honduras. Przyczyną inwazji wojsk Nikaragui na Kostarykę w 2010 r. był błąd na mapach Google - niewielki obszar terytorium Kostaryki zaznaczony został jako należący do sąsiedzkiego państwa. Władze Nikaragui potraktowały ów błąd jako pretekst do zajęcia rzeczonego terytorium. 
odpowiedź na pytanie, jak wielu członków FARC faktycznie złoży broń. Już teraz można przyjąć, iż z pewnością nie będą to wszyscy guerrilleros. Wielu byłych członków FARC zaangażuje się bowiem w działalność przestępczą innego typu, nastawioną głównie na czerpanie zysków z dochodowego handlu narkotykami.

2017 to również rok rozpoczęcia negocjacji pokojowych z drugą kolumbijską bojówką uznawaną za grupę terrorystyczną, ELN. Biorąc jednak pod uwagę, iż rozmowy z FARC trwały kilka lat, trudno zakładać, iż negocjacje z ELN zakończą się w roku ich rozpoczęcia. Mało prawdopodobne jest również, iż w 2017 r. dojdzie do przełomu w walkach wojska peruwiańskiego ze Świetlistym Szlakiem. Nie można wykluczyć kolejnych sukcesów sił rządowych, jednak ostateczne zwycięstwo nad bojówką uznać należy w tak krótkiej perspektywie czasowej za scenariusz nierealistyczny.

Nierealistyczne jest również założenie, iż rok 2017 przyniesie znaczącą poprawę w meksykańskiej wojnie z kartelami narkotykowymi. Wszelkie statystyki wskazują bowiem, iż problem pogłębia się, a dotychczasowa strategia władz państwowych nie przynosi porządnych rezultatów. Nie jest wykluczone podjęcie przez władzę refleksji w tym zakresie, jednak żadna zmiana sposobu walki z kartelami narkotykowymi nie pozwoli na osiagnięcie efektów w tak krótkim czasie. Trudno również oczekiwać znaczących zmian w skali przestępczości zorganizowanej w Ameryce Łacińskiej. Nie ulega wątpliwości, iż zjawisko to niosło będzie za sobą krwawe żniwo, którego nie sposób jest powstrzymać w ciagu zaledwie jednego roku. Co więcej, ze względu na rosnący popyt na używki w samej Ameryce Łacińskiej, można domniemywać, iż pojawiać się będą nowe grupy przestępcze, czerpiące zyski głównie z tego procederu.

\section{Prognoza dlugoterminowa}

Dłuższa niż jednoroczna perspektywa czasowa pozwala zauważyć wielość wyzwań stojących przed Ameryką Łacińską w zakresie bezpieczeństwa. Jak wielokrotnie zostało bowiem podkreślone, zagrożenia występujące w regionie mają charakter długotrwały.

Generalna obserwacja sporów terytorialnych w Ameryce Łacińskiej, szczególnie ich przewlekłego charakteru, utrudnia prognozowanie ich potencjalnego rozwiązania. Nawet drobne incydenty stanowić mogą bowiem pretekst do zbrojnej interwencji. Eskalacja społecznej frustracji następuje najczęściej w kontekście pogłębionych problemów społecznych, politycznych i gospodarczych, których w regionie Ameryki Łacińskiej absolutnie nie można wykluczyć.

Mówiąc o toczących się w regionie sporach terytorialnych, należy pamiętać o rosnącej roli Międzynarodowego Trybunału Sprawiedliwości w procesie ich rozwiązywania. Od wyroku MTS w sporze boliwijsko-chilijskim zależeć będzie dalszy przebieg dyskusji między dwoma państwami. Trudno przewidywać zarówno wyrok trybunału, jak i reakcję władz obu rządów. Nie można wykluczyć scenariusza, w którym Chile bądź Boliwia nie pogodzą się z decyzją MTS i odmówią wykonania wyroku, co prowadzić może do eskalacji konfliktu. W tym przypadku wiele zależeć będzie od orientacji politycznej sprawujących władzę $w$ dwóch państwach. Jest to szczególnie istotne w kontekście faktu, iż w 2017 r. zarówno w Boliwii, jak i w Chile odbędą się wybory prezydenckie. 
Wpływ identyfikacji politycznej przywódcy na dynamikę prowadzonego przez państwo sporu terytorialnego bardzo dobrze widać w przypadku stosunku Argentyny do terytorium Falklandów. Wyważona postawa obecnie sprawującego władzę prezydenta Mauricia Macriego bardzo silnie kontrastuje z polityką prowadzoną w państwie w latach 2003-2015. Nie ma gwarancji, iż w obliczu przyszłej zmiany władzy w państwie zostanie ona utrzymana. Nawet w dłuższej perspektywie czasowej jednak, rozwiązanie sporu falklandzkiego w kształcie w pełni satysfakcjonującym obie strony jest w praktyce niemożliwe, gdyż zarówno jedno, jak i drugie państwo traktują pełną suwerenność nad archipelagiem jako najbardziej pożądany scenariusz. Nie jest jednak wykluczone zacieśnienie argentyńsko-brytyjskiej współpracy.

Doświadczenia ostatnich lat ukazują, iż terroryzm oparty na skrajnie lewicowych ideologiach jest w Ameryce Łacińskiej bardziej symbolem czasów minionych, niż eskalującym zagrożeniem. Demobilizacja FARC, jak również porozumienie z ELN, którego podpisanie w dłuższej niż jednorocznej perspektywie uznać można za bardzo prawdopodobne, doprowadziłyby do wykreślenia Kolumbii z amerykańskiej listy państw, w których działaja grupy terrorystyczne. Trzeba jednak wyraźnie podkreślić, iż poradzenie sobie z FARC i ELN nie będzie równoznaczne z przerwaniem spirali przemocy w Kolumbii. Problemem pozostaną bowiem grupy narcoparamilitares.

Sprawą otwartą pozostaje kwestia potencjalnego zwiększenia problemu terroryzmu opartego o fundamentalizm islamski. Trudno zakładać, aby Ameryka Łacińska stała się głównym celem terrorystów związanych z tzw. Państwem Islamskim. Mimo to, przeprowadzenie ataku w regionie nie jest wykluczone, a jako wyjątkowo narażone określić należy Argentynę i Urugwaj. Państwa te, szczególnie zaś ich stolice, mają charakter kosmopolityczny, co stanowi skutek wieloletnich fal migracyjnych, docierających na te obszary nie tylko z Europy, ale również z Bliskiego Wschodu.

Zmniejszenie zagrożenia tradycyjnymi formami terroryzmu w Ameryce Łacińskiej nie sprawi jednak, że region ten stanie się całościowo bardziej bezpieczny. W dłuższej perspektywie następować będzie dalsze przejście grup terrorystycznych w stronę przestępczości zorganizowanej, nastawionej na zysk i pozbawionej filara ideologicznego. Szczególnie istotną rolę w dalszym ciągu odgrywać będzie handel narkotykami. Walka z owym procederem trwać będzie nadal, mimo braku długofalowych sukcesów, co szczególnie widoczne jest w Meksyku. $Z$ dużą dozą prawdopodobieństwa można jednak zakładać, iż władze meksykańskie będą w przyszłości dążyć do rewizji sposobu walki z kartelami narkotykowymi, podobnie jak innymi generującymi przemoc działaniami o charakterze nielegalnym. Wyzwaniem dla latynoamerykańskich liderów będzie jednak przekłucie wiedzy na temat strukturalnego charakteru przestępczości w Ameryce Łacińskiej na szeroko zakrojone, wielopłaszczyznowe działania, bardzo często wiążące się z pracą u podstaw. Skuteczne ukrócenie przestępczości zorganizowanej w Ameryce Łacińskiej musi wiązać się z odpowiednio dobraną polityką społeczną i edukacyjną. Innymi słowy, jednostki, które przystępują do karteli i gangów, gdyż nie widzą dla siebie innej możliwości, muszą nabrać realnego przekonania, iż alternatywa jest możliwa. Bez wypracowania owej zmiany niemożliwe będzie trwałe wyjście ze spirali przemocy, a co za tym idzie, zwiększenie bezpieczeństwa regionu. Rosnący poziom przestępczości zorganizowanej we wszystkich praktycznie państwach latynoamerykańskich pozwala zakładać, iż w części z nich podjęta zostanie 
przynajmniej próba zaprowadzenia opisanych zmian. Ze względu jednak na fakt, iż efekty tego typu transformacji są z natury odłożone w czasie, nie należy spodziewać się spektakularnej zmiany w poziomie bezpieczeństwa w Ameryce Łacińskiej w ciagu najbliższych kilku lat.

\section{BIBLIOGRAFIA}

Almonacid R. (2017), En 2016 asesinaron a 80 lideres sociales; 55\% a manos de herederos del paramilitarismo, 22.02.2017, http://www.elespectador.com/noticias/paz/en-2016-asesinaron-80lideres-sociales-55-manos-de-herederos-del-paramilitarismo-articulo-681364 (23.02.2017).

Así fueron las votaciones del plebiscito de la paz en las regiones, 2.10.2016, http://www.elespectador.com/noticias/paz/asi-fueron-votaciones-del-plebiscito-de-paz-regiones-articulo-658180 (22.02.2017).

Brodzinsky S. (2016), Colombia referendum: voters reject peace deal with Farc guerrillas, 3.10.2017, https://www.theguardian.com/world/2016/oct/02/colombia-referendum-rejects-peace-dealwith-farc (22.02.2017).

Cacelín J. (2016), La guerra contra el narco cumple 10 años en México y las cifras de violencia no dan tregua, 6.12.2016, http://www.univision.com/noticias/asesinatos/la-guerra-contra-elnarco-cumple-10-anos-en-mexico-y-las-cifras-de-violencia-no-dan-tregua (23.02.2017).

Castellanos J. F. (2016), Surge "La Nueva Familia" en Michoacán y declara la guerra al CJNG, 6.02.2017, http://www.proceso.com.mx/429152/aparecen-mantas-a-nombre-de-la-nuevafamilia-michoacana (24.02.2017).

Clavel T. (2016), Drug Bust Points to Evolving Criminal Structures in Costa Rica, 10.11.2017, http:// www.insightcrime.org/news-briefs/drug-bust-points-to-evolving-criminal-structures-in-costa-rica (24.02.2017).

Congreso refrendó el nuevo acuerdo de paz, ahora viene la fase de implementación (2016), 30.11.2016, http://www.elespectador.com/noticias/paz/camara-refrendo-el-nuevo-acuerdode-paz-articulo-668311 (22.02.2017).

Cosoy N. (2016), Colombia anuncia diálogos de paz con el ELN, la segunda guerrilla más grande del pais, 30.03.2016, http://www.bbc.com/mundo/noticias/2016/03/160330_colombia_anuncio_negociacion_paz_con_eln_nc (23.02.2017).

Darío Melgar Choc R. (2016), Petén: familias en San José Las Flores abandonaron sus tierras por temor a ejército beliceño, 24.11.2016, http://www.prensacomunitaria.org/peten-familias-ensan-jose-las-flores-abandonaron-sus-tierras-por-temor-a-ejercito-beliceno/ (22.02.2017).

Daugherty A. (2016), Officials' Arrest Indicative of Split in Venezuela's 'Cartel of the Suns'?, 17.02.2016, http://www.insightcrime.org/news-briefs/army-official-arrest-indicative-splitvenezuela-cartel-of-the-suns (25.02.2017).

Delgado A. M. (2016), Arrestan a oficial venezolano, presunto miembro del Cartel de los Soles, 18.06.2016, http://www.elnuevoherald.com/noticias/mundo/america-latina/venezuela-es/article84639037.html (25.02.2017).

Encuentran cadáver del alcalde de San Dionisio, Usulután (2016), 14.04.2016, http:/diario1.com/ nacionales/2016/04/encuentran-cadaver-del-alcalde-de-san-dionisio-usulutan/ (25.02.2017).

Guerra narco en Paraguay: mataron de 16 tiros al capo „Sadam” Toumani (2016), 16.06.2016, http://www.infobae.com/america/america-latina/2016/06/16/guerra-narco-en-paraguay-mataron-de-16-tiros-al-capo-sadam-toumani/ (24.02.2017). 
Fajardo J. (2016), Colombia y las FARC firman la paz en una jornada histórica, 27.09.2016, http://www.elmundo.es/internacional/2016/09/26/57e978f722601d34098b4650.html (22.02.2017).

Fleischman L. (2016), Venezuela Flaunts It's Status As A Narco-State, 9.08.2016, http://www. centerforsecuritypolicy.org/2016/08/09/venezuela-flaunts-its-status-as-a-narco-state/ (25.02.2017).

Fowks J. (2016), Diez muertos por una emboscada de Sendero Luminoso en Perú, 11.04.2016, http://internacional.elpais.com/internacional/2016/04/10/america/1460248838_648470.html (23.02.2017).

Fregoso J. (2016), México cumple 10 años de guerra contra el narcotráfico: mucho show, muchos muertos y sin final a la vista, 4.12.2016, http://www.infobae.com/america/america-latina/2016/12/04/mexico-cumple-10-anos-de-guerra-a-los-narcos-con-mucho-show-muchosmuertos-y-sin-final-a-la-vista/ (23.02.2017).

Guatemala despliega 3.000 soldados en la frontera con Belice (2016), 22.04.2016, http://www.elmundo.es/internacional/2016/04/22/57196e78268e3ebb728b45b5.html (22.02.2017).

Guatemalan troops mass near Belize border after shooting incident (2016), 22.04.2016, https:// www.theguardian.com/world/2016/apr/22/guatemalan-troops-mass-belize-border-shootingincident (22.02.2017).

Hurrell A. (1998), Security in Latin America, „International Affairs”, Vol. 74, No. 3.

Insight Crime Foundation (2016), Game Changers 2016. Tracking the Evolution of Organized Crime in the Americas, http://www.insightcrime.org/images/PDFs/2017/GameChangers2016.pdf (24.02.2017).

Jiménez B. E. (2016), Balacera en Cieneguita cobra su quinta víctima: muere niño de 11 años, 10.10.2016, http://www.nacion.com/sucesos/crimenes-asaltos/Balacera-Cieneguita-Limonquinta-victima_0_1589241095.html (24.02.2017).

La ONU llevará a la CIJ la disputa Venezuela-Guyana si no se avanza en 2017 (2016), 16.12.2016, http://www.efe.com/efe/america/politica/la-onu-llevara-a-cij-disputa-venezuela-guyana-sino-se-avanza-en-2017/20000035-3127424 (22.02.2017).

Martínez Ahrens J. (2016), El regreso del Narco de Narcos abre una guerra de cárteles en México, 7.07.2016, http://internacional.elpais.com/internacional/2016/07/06/mexico/1467824703_253910.html (24.02.2017).

Matan a un alto mando de Sendero Luminoso en el Vraem (2016), 20.05.2016, http://rpp.pe/ peru/ayacucho/dos-terroristas-muertos-tras-enfrentamientos-en-el-vraem-noticia-963973 (23.02.2017).

Montes R. (2016), Chile demanda a Bolivia ante La Haya por el río Silala, 6.06.2016, http://internacional.elpais.com/internacional/2016/06/06/america/1465220907_619311.html (22.02.2017).

Murder Rates By Country (2016), 28.09.2016, http://www.worldatlas.com/articles/murder-rates-bycountry.html (25.02.2017).

Obarrio M. (2016), Malvinas: Macri planteó el reclamo de soberanía a la premier británica, 21.09.2016, http://www.lanacion.com.ar/1939856-malvinas-macri-planteo-el-reclamo-desoberania-a-la-premier-britanica (22.02.2017).

Oppenheimer A. (2016), Will ISIS strike in Latin America?, 1.04.2016, http://www.miamiherald.com/ news/local/news-columns-blogs/andres-oppenheimer/article69707752.html (26.02.2017).

Partlow J., Maslin S. E. (2016), El Salvador's gangs call a cease-fire, but many doubt it will hold, 3.04.2016, https:/www.washingtonpost.com/world/the_americas/el-salvadors-gangscall-a-cease-fire-but-many-doubt-it-will-hold/2016/04/02/79222748-f5c2-11e5-958dd038dac6e718_story.html (25.02.2017). 
Paullier J. (2016), 10 años de la guerra contra el narcotráfico en México: Juan Villoro habla sobre la esquizofrenia del país y por qué "toda bala es una bala perdida”, 11.12.2016, http://www. bbc.com/mundo/noticias-america-latina-38191600 (23.02.2017).

Píriz D., Correa J. P. (2016), Investigan vínculo islamista del asesino del comerciante judio, 9.03.2016, http://www.elpais.com.uy/informacion/investigan-vinculo-islamista-asesino-comerciante. html (26.02.2017).

Perú: 10 muertos en un ataque de Sendero Luminoso (2016), 11.04.2016, http://www.bbc.com/mundo/noticias/2016/04/160409_peru_ataque_sendero_luminoso_elecciones_all (23.02.2017).

Ramos D., Esposito A. (2016), Bolivia's Morales accuses Chile of setting up military base near border, 8.05.2016, http://www.reuters.com/article/us-bolivia-chile-border-idUSKCN0XZ0QF (22.02.2017).

Reina E. (2016), Asesinado de un balazo el juez que frenó la extradición de El Chapo Guzmán, 21.10.2016, http://internacional.elpais.com/internacional/2016/10/17/mexico/1476736865_187180.html (23.02.2017).

Sánchez A. (2016), Detienen a jefe de plaza de los Beltrán Leyva en Sonora, 29.12.2016, http:// www.eluniversal.com.mx/articulo/nacion/seguridad/2016/12/29/detienen-jefe-de-plaza-delos-beltran-leyva-en-sonora (23.02.2017).

Secretaría de Gobernación (2017), Informe de víctimas de homicidio, secuestro y extorsión 2016, 20.02.2017, http://secretariadoejecutivo.gob.mx/docs/pdfs/victimas/Victimas2016_012017. pdf (23.02.2017).

Seguridad, Justicia y Paz, Consejo Ciudadano para la Seguridad Pública y Justicia Penal A.C. (2016), Caracas, Venezuela the most violent city in the world, 24.01.2016, http://www.seguridadjusticiaypaz.org.mx/biblioteca/prensa/send/6-prensa/231-caracas-venezuela-the-most-violent-city-in-the-world (26.02.2017).

Semprun A. (2016), ¿Por qué Venezuela es un narcoestado?, 9.08.2016, http://www.elnuevoherald. com/opinion-es/cartas/article94695587.html (25.02.2017).

Sigue la guerra narco en Paraguay: sicarios asesinaron a tres personas (2016), 20.06.2016, http:// www.infobae.com/america/america-latina/2016/06/20/sigue-la-guerra-narco-en-paraguaysicarios-asesinaron-a-tres-personas/ (24.02.2016).

Spyra J. (2006), Problemy bezpieczeństwa w Ameryce Łacińskiej, w: Ameryka Lacińska we wspótczesnym świecie, (red.) M. F. Gawrycki, Warszawa.

Sube a 11 cifra de asesinados en San Juan Opico, La Libertad (2016), 3.03.2016, http://diario1. com/nacionales/2016/03/sube-a-11-cifra-de-asesinados-en-san-juan-opico-la-libertad/ (25.02.2017).

Tratado para la Proscripción de las Armas Nucleares en la América Latina y el Caribe, Tratado de Tlatelolco (1967), OPANAL, http://www.opanal.org/texto-del-tratado-de-tlatelolco/ (26.02.2017).

UNODC, United Nations Office on Drugs and Crime (2014), Global Study on Homicide 2013, Vienna 2014.

Usi E. (2016), Óscar Arias: „Venezuela es un narcoestado”, 12.11.2016, http://www.dw.com/ es/\%C3\%B3scar-arias-venezuela-es-un-narcoestado/a-36372093 (25.02.2017).

Wojna B. (2008), Bezpieczeństwo Ameryki Łacińskiej i Karaibów, w: Bezpieczeństwo międzynarodowe po zimnej wojnie, (red.) R. Zięba, Warszawa.

Yagoub M. (2016), Arrest of Panama Drug Boss Shows Gangs'International Ambitions, 8.09.2017, http://www.insightcrime.org/news-briefs/top-drug-boss-arrest-reveals-power-of-panamagangs (24.02.2017). 


\title{
STRESZCZENIE
}

Artykuł stanowi analizę stanu bezpieczeństwa w Ameryce Łacińskiej w roku 2016, biorąc pod uwagę charakter istniejących w regionie zagrożeń. W pierwszej kolejności przedstawione zostały problemy wynikające z toczących się między państwami latynoamerykańskimi sporów granicznych. Następnie, w kontekście wydarzeń z roku 2016, omówiony został problem terroryzmu w Ameryce Łacińskiej. Ostatnia część właściwej analizy poświęcona jest przestępczości zorganizowanej i generowanych przez nią zagrożeniom. Szczególny nacisk położony został na problem narkobiznesu. Zwieńczenie artykułu stanowi podsumowanie omawianych kwestii, jak również prognoza o dwojakim charakterze: krótkoterminowa, dotycząca roku 2017, oraz długoterminowa, wykraczająca poza bieżący rok.

Słowa kluczowe: Ameryka Łacińska, bezpieczeństwo regionalne, przestępczość zorganizowana, terroryzm, spory terytorialne

\section{THE STATE OF SECURITY IN LATIN AMERICA IN 2016}

\begin{abstract}
The article provides an analysis of security in Latin America in 2016, taking into account the nature of threats that exist in the region. The first part of the paper presents the problems arising from ongoing border disputes between Latin American countries. Then, the issue of Latin American terrorism is discussed in light of events 2016. The third part is dedicated to organized crime in Latin America and the threats it generates. A special focus has been placed on the issue of illegal drug trade. The last part covers the conclusion stemming from the considerations developed in the article, as well as a two-part forecast. The first one is short-term and applies for 2017. The second one is a long-term forecast and goes beyond 2017.
\end{abstract}

Keywords: Latin America, regional security, organized crime, terrorism, territorial disputes 
